\title{
Peltobioenergian mahdollisuudet ja haasteet
}

\author{
Ahokas $\mathrm{J}^{1}$. \& Mikkola $\mathrm{H}^{2}$. \\ ${ }^{1}$ Helsingin Yliopisto Agroteknologian laitos, jukka.ahokas@helsinki.fi \\ ${ }^{2}$ Helsingin Yliopisto Agroteknologian laitos, hannu.j.mikkola@helsinki.fi
}

\section{Tiivistelmä}

Bioenergian mielikuvana on luonnonmukainen tuote ja se antaa polttoaineelle 'vihreän' ilmeen. Bioenergian tuotannosta on kuitenkin muistettava, että mitä pidemmälle tuotetta jalostetaan, sitä enemmän kulutetaan jalostukseen energiaa ja tuotetaan päästöjä. Kun nämä summataan yhteen, voidaan tulla tilanteeseen, jossa biopolttoaine on kuluttanut tuotantovaiheessa runsaasti energiaa ja tuottanut päästöjä ja sen kokonaishyöty voi jäädä vähäiseksi. Tuotannosta on tehtävä sekä energia- että päästöanalyysit, jotta tuotannon järkevyyttä voitaisiin arvioida ja sitä voitaisiin kehittää ympäristöystävällisempään suuntaan.

Peltobioenergia kilpailee ruuan tuotannon kanssa. Tällä hetkellä arvioidaan, että maassamme olisi 0,5 milj. ha käytettävissä peltobioenergian tuotantoon. Ruuan ja rehun tuotannosta on muistettava, että suuret sadot perustuvat erityisesti typpilannoitukseen ja typen valmistus on runsaasti energiaa kuluttava prosessi. Jos väkilannoitteiden käyttö vähenee esim. hinnan tai saatavuuden takia, myös satotasot alenevat ja suurempi ala pelloista tarvitaan ruuan ja rehun tuotantoon. Maailmanlaajuisesti maapallon väkimäärä on jatkuvassa kasvussa, jolloin tarvitaan myös enemmän ruokaa. Tämä tarvitsee suurempia peltoaloja eli tulevaisuudessa peltobioenergian tuotantoon ei välttämättä ole kovin suuria aloja käytettävissä.

Nykyisin pellolla tapahtuva tuotanto on joko ruuan, rehun tai kuitujen tuotantoa. Kasvit on jalostettu tätä tarkoitusta varten. Peltobioenergian tuotantoon tarvitaan hieman erilaista lähestymistapaa, pääasiana onkin runsaan ja energiakäyttöön sopivan kokonaismassan tuotanto. Tämä tarkoittaa erityyppisten kasvien tarvetta ja myös niiden jalostamista energian tuotannon kannalta. Biomateriaalien tuotannossa pitää pyrkiä niiden kokonaishyödyntämiseen. Esimerkiksi etanolin tai biodieselin tuotannossa on oleellista, että prosessissa syntyvät 'jätteet', rankki ja rouhe käytetään eläinten rehuksi ja olki energiaksi. Tällöin energiasuhteet saadaan korkeiksi.

Bioenergian tuotannossa on muistettava myös taloudelliset ja tekniset edellytykset. Bioenergian käyttöön tai tuotantoon liittyy investointeja ja huoltotyötä, jotka aiheuttavat kustannuksia. Tämän takia yhteiskunta joutuu usein tukemaan bioenergian käyttöä, koska fossiilista polttoainetta on saatavissa halvemmalla kuin bioenergiaa. Bioenergian käyttö aiheuttaa myös teknisiä muutoksia, tuotantoketjut on rakennettava ja koneistettava. Lisäksi biopolttoaineet poikkeavat fossiilisista polttoaineista, jolloin esim. poltto- ja moottoritekniikassa tarvitaan muutoksia.

Tällä hetkellä osa peltoalasta voidaan käyttää bioenergian tuotantoon ja sillä voidaan korvata osa fossiilisen energian käytöstä. Peltoa voidaan kuitenkin myöhemmin tarvita ruuan ja rehun tuotantoon, joten peltobioenergia ei välttämättä ole lopullinen ratkaisu. Peltobioenergian tuotantoa täytyy kehittää kokonaisvaltaisesti edelleen siten, että otetaan tarkasteluun mukaan kaikki näkökannat ja pyritään saamaan aikaiseksi ekologinen ja kestävä ratkaisu.

Peltobioenergian tuotantoon liittyvät analyysit eivät ole nykyisellään kovin tarkkoja, epävarmuudeksi ja vaihteluksi on arvioitu jopa 100 prosentin luokkaa. Analyyseissä pitäisi päästä tarkempiin arvioihin, tämä tietäisi menetelmien standardisointia sekä lähtötietojen tarkempaa selvitystä. Ongelmana on myös vuotuiset säävaihtelut, viljelyyn tarvittavat energiamäärä, tuotteen kuivatus ja dityppioksidipäästöt riippuvat sääoloista.

Asiasanat: bioenergia, energia-analyysi, päästöanalyysi 


\section{Johdanto}

Bioenergian käyttöä halutaan lisätä EU:ssa kaikilla energiankäytön alueilla. Lämmön ja sähkön tuotannossa tämä on helpompaa, mutta polttomoottorikäytössä lisäys on ongelmallisempaa. Liikenne on lähes täysin riippuvainen fossiilisista polttoaineista ja liikenteen käyttämä energiamäärä kasvaa koko ajan. Siksi biopolttoaineita halutaan saada myös liikennekäyttöön. Sinänsä moottorit saadaan toimimaan mitä erilaisimmilla polttoaineilla, mutta moottoreiden käytettävyys, kestävyys tai päästöt voivat olla ongelmallisia, kun niissä käytetään normaalista poikkeavia polttoaineita. Biopolttoaineiden pitäisi olla laadultaan korkeatasoisia ja kaikissa käyttöolosuhteissa toimivia.

Bioenergiaa voidaan tuottaa joko metsä- tai peltoperäisistä biomassoista. Näiden lisäksi voidaan hyödyntää erilaisia tuotannon sivutuotteita tai jätteitä. Bioenergian mielikuva luonnonmukaisena tuotteena antaa sille 'vihreän' ilmeen. On kuitenkin muistettava, että mitä pidemmälle tuotetta jalostetaan, sitä enemmän kulutetaan jalostukseen energiaa ja tuotetaan päästöjä. Kun nämä summataan yhteen, voidaan tulla tilanteeseen, jossa biopolttoaine on tuotantovaiheessa kuluttanut runsaasti energiaa ja tuottanut päästöjä. Bioenergian kokonaishyöty voi jäädä vähäiseksi tai se voi olla negatiivinen, tuotantoon käytettiin enemmän energiaa, kuin mitä itse tuotteessa on. Bioenergian tuotannossa on tehtävä sekä energia- että päästöanalyysi, jotta tuotannon järkevyyttä voitaisiin arvioida ja tuotantoa voitaisiin kehittää tehokkaampaan suuntaan.

Peltobioenergia kilpailee ruuan tuotannon kanssa. Tällä hetkellä arvioidaan, että maassamme olisi 0,5 milj. ha käytettävissä peltobioenergian tuotantoon. Ruuan ja rehun tuotannosta on muistettava, että suuret sadot perustuvat riittävään ravinteiden saantiin. Nämä ravinteet eli lannoitteet ovat suurimmaksi osaksi väkilannoitteita ja erityisesti typen valmistamiseen tarvitaan paljon energiaa. Jos väkilannoitteiden käyttö vähenee esim. hinnan tai saatavuuden takia, myös satotasot alenevat ja suurempi ala pelloista tarvitaan ruuan ja rehun tuotantoon. Maailmanlaajuisesti maapallon väkimäärä on jatkuvassa kasvussa, jolloin tarvitaan myös enemmän ruokaa. Tämä tarvitsee suurempia peltoaloja eli bioenergian tuotantoon ei välttämättä ole kovin suuria aloja käytettävissä.

Pellolla tapahtuva tuotanto on joko ruuan, rehun tai kuitujen tuotantoa. Kasvit on jalostettu tätä tarkoitusta varten. Peltobioenergian tuotantoon tarvitaan hieman erilaista lähestymistapaa, pääasiana voikin olla runsaan kokonaismassan tuotanto. Samoin pitää pyrkiä biomateriaalien kokonaishyödyntämiseen. Esimerkiksi etanolin tai biodieselin tuotannossa on oleellista, että prosessissa syntyvät 'jätteet', rankki ja rouhe käytetään eläinten rehuksi ja olki energiaksi.

Edellä olleiden seikkojen lisäksi tulevat bioenergian taloudelliset mahdollisuudet. Sen käyttöön tai tuotantoon liittyy investointeja ja huoltotyötä, jotka lisäävät kustannuksia. Tämän takia yhteiskunta joutuu usein tukemaan bioenergian käyttöä, koska fossiilista polttoainetta on saatavissa halvemmalla kuin bioenergia.

\section{Peltobioenergian tuotantoon käytet- tävissä oleva peltoala}

Kuva 1 esittää maapallon pellon käyttöä, viljasatoa ja lannoitteiden tuotantoa vuosina 1955 - 1995 (Kitani 1999). Samana aikavälinä maapallon väestömäärä on kaksinkertaistunut 2,7 miljardista 5,7 miljardiin henkilöön. Väestönkasvu jatkuu samansuuntaisena ja vuoden 2040 jälkeen väestömäärän on ennustettu ylittävän 9 miljardin rajan (Anon. 2007a). Vaikka maapallon väestömäärä on vuosien 19551995 aikana kaksinkertaistunut, peltoala on lisääntynyt vain hieman. Samanaikaisesti viljasato on kaksinkertaistunut ja lannoitetuotanto (käyttö) on seitsenkertaistunut. Lisääntynyt väestö on siten pystytty ruokkimaan satotason nousun kautta, minkä on tehnyt mahdolliseksi lannoitteiden lisääntynyt käyttö. Suurin osa lannoitteista on taasen valmistettu fossiilisten energioiden avulla. Maapallon

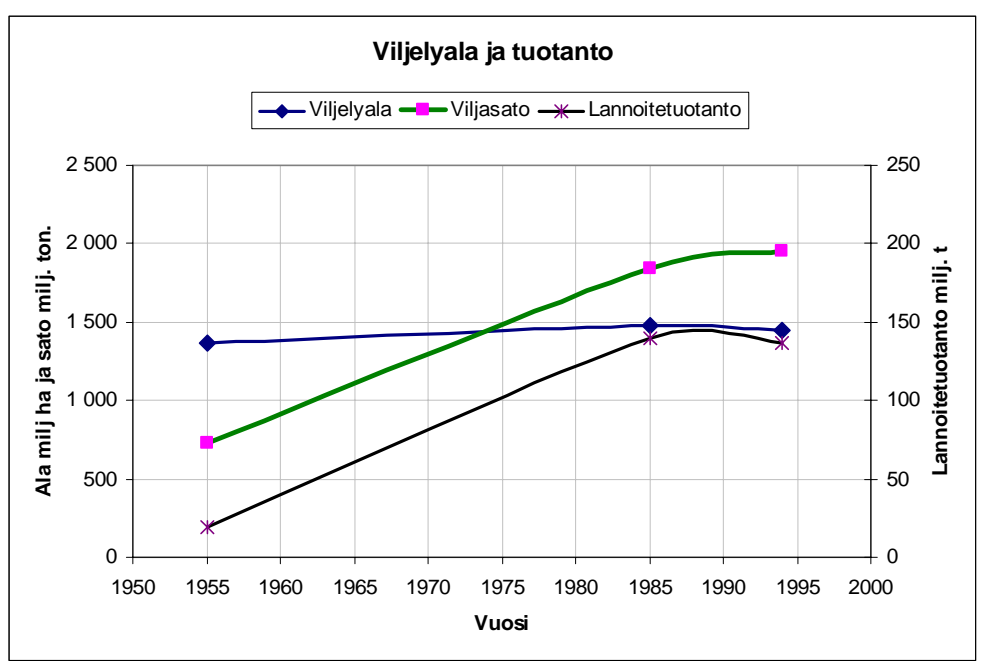

Kuva 1. Maapallon viljelyala, lannoitetuotanto ja satotasot (Kitani 1999) 
lisääntynyt ruuan tuotanto on siten pääasiassa fossiilisen energian ansiota. Tämä on ongelmallista, koska fossiilisen energian väheneminen ja saantihäiriöt aiheuttavat nopeasti lannoitteen saatavuudessa ja hinnassa muutoksia ja sitä kautta myös ravinnon saannissa tulee muutoksia.

Meillä peltoala on pysynyt lähes samana viimeisten 40 vuoden aikana. Vuonna 2006 kokonaispeltoala oli 2,3 milj ha ( Tietohaarukka 2007). Ravintoon tarvittava peltoala riippuu ruokailutottumuksista. Jos ruokana käytettäisiin suoraan viljaa leipänä, maamme väestön ravitsemiseen tarvittaisiin n 700000 ha ala. Ihmisten ruokatottumusten ja monipuolisen ravinnon saannin takia pelkkä viljaruoka ei riitä, vaan tarvitaan maito- ja lihatuotteita. Kun pellon tuotto kierrätetään eläinten kautta, energiasuhde heikkenee. Esimerkiksi maidossa on n 20 \% siitä energiamäärästä, mitä tuotantoon on käytetty (Cavalchini 1999), kun taasen viljassa päästään aina positiiviseen energiasuhteeseen. Toisaalta ihmiset eivät voi käyttää kaikkia kasveja ravinnoksi, vaan ne pitää ensin kierrättää eläinten kautta. Suomen elintarvikeomavaraisuus on hyvä ja esimerkiksi maitotuotteissa, kananmunissa ja sianlihassa meillä on ylituotantoa (Tietohaarukka 2007).

Suomessa on tehty useita arvioita bioenergian tuotantoon käytettävissä olevasta peltoalasta. Useimmissa näissä peltoalaksi on saatu 500000 ha. Samoin bioenergian lisäysmahdollisuuksista on valmistunut useita raportteja. Bioenergian lisäysmahdollisuudet ovat selvästi rajallisemmat, kuin fossiilisen energian lisäysmahdollisuudet ovat olleet ja ovat edelleenkin. Jos kokonaisenergian kulutus lisääntyy jatkuvasti, bioenergian osuuden prosentuaalinen lisääminen on vaikeata. Mikäli Suomessa otetaan käyttöön kiihdytetyt toimenpiteet bioenergian osuuden lisäämiseksi siten, että vuonna 2015 bioenergiaa käytettäisiin n 500 PJ (Anon 2007b), bioenergian osuus kasvaa 26 prosentista 32 prosenttiin, kun laskelmissa otetaan huomioon energian käytön jatkuva lisääntyminen.

Jos Suomen koko peltoala käytettäisiin energiaviljan tuotantoon, maamme kokonaisenergian kulutuksesta voitaisiin korvata suorassa viljan poltossa $8 \%$. Jos tuotantoon kuluva energia otetaan huomioon, korvattava määrä on $5 \%$.

\section{Peltobioenergian energia-analyysi}

Kun biomassaa käytetään energian tuotantoon, pitää ottaa huomioon myös biomassan tuotantoon tarvittava energia. Tämä voidaan laskea eri tavoilla, energiasuhde on lopullisessa tuotteessa olevan energian suhde tuotantoon käytettyyn energiaan. Tämän käänteislukua käytetään myös, ja silloin puhutaan primäärienergiapanoksesta. Nettoenergiansaanto kuvaa sitä, kuinka paljon nettoenergiaa on saatu tuotannossa. Se saadaan vähentämällä tuotteen energiasta tuotantoon tarvittava energia. Energian käyttö jakaantuu kahteen osaan, suoraan ja epäsuoraan energian käyttöön. Suora energian käyttö tarkoittaa tuotannossa käytettyjä polttoaineita ja sähköä. Epäsuorassa on mukana erilaiset valmistusenergiat, kuten lannoitteet, koneet ja rakennukset. Epäsuora energia muodostaa usein suurimman osan energian kulutuksesta. (Ortiz-Canavate ja Hernanz 1999).

Etenkin epäsuoran energian käyttölukuja on vaikea saada, koska kyse on erilaisten tuotteiden valmistukseen käytetyistä energiamääristä, joita ei välttämättä kirjata ja ne hajaantuvat useiden alihankkijoiden ja kuljetusten kesken. Erilaiset lähtöluvut aikaansaavat sen, että energia-analyysin tulokset ovat epätarkkoja.

Kuvassa 2 on esimerkki energian käytöstä etanolin tuotannossa. Suurimpana energiatarpeena on itse etanolin valmistus, käyttäminen ja tislaus. Seuraavina tulevat lannoitteet, sadon kuivaus ja maataloustyöt. Energian käyttöön viljelyssä vaikuttavat myös säät ja maalajit. Esimerkiksi kuivausenergian tarve kaksinkertaistuu märkinä syksyinä. Mäkinen ym. (2006) mukaan ohran tuotannon energiatase on luokkaa $4-6$ ja rypsin 3,4-3,6. Kun verrataan bioenergian tuotannon energiasuhteita, saadaan kuvan 3 mukaisia tuloksia. Etanolin energiasuhde on lähellä yhtä ja sen käyttö energian lähteenä on kyseenalaista verrattuna itse ohran käyttämiseen vaikkapa suoraan polttoaineena. Etanolin tuotannossa on hävinnyt Energian käyttö etanolin tuotannossa Hyvät olosuhteet, energian tarve 734 l pö/ha

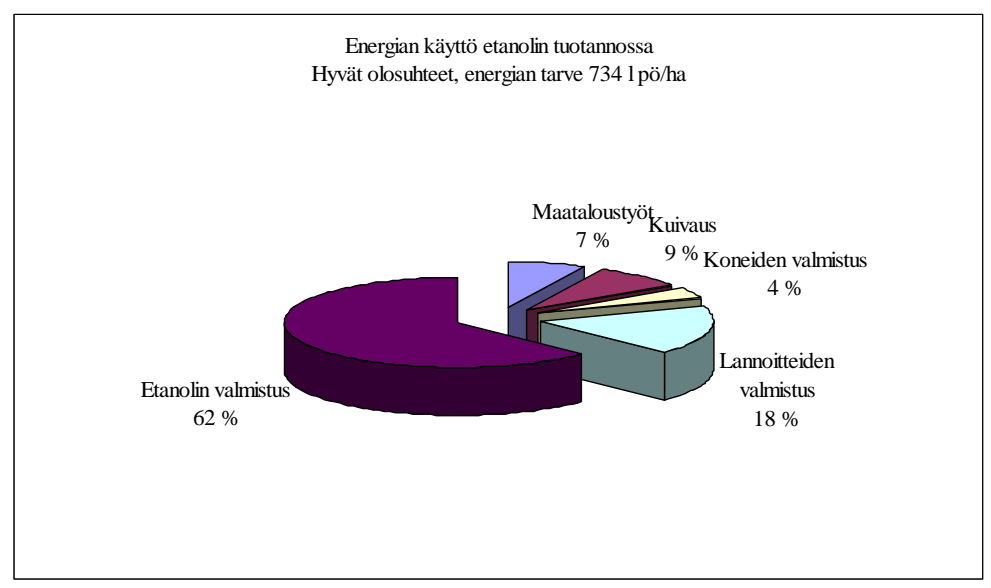

Kuva 2. Esimerkki etanolin valmistuksessa käytettävän energian jakautumisesta merkittävä osa energiasta. Biodieselin valmistuksessa tai Fischer-Tropsch menetelmän mukaisessa energian 
tuotannossa päästään jo parempiin energiasuhteisiin kuin etanolin tuotannossa. Biokaasun tuotannossa energiasuhteet ovat korkeat, ne ovat suuruusluokaltaan 2,5 -5, kun raaka-aineena on biomassa (Tuomisto 2006, Berglund ja Börjesson 2006). Edellä olevat luvut on laskettu polttoaineessa olevan energian perusteella. Jos biokaasulla tuotetaan sähköä, energiasuhde on 1 - 2, koska parhaimmillaankin keskikokoluokan moottori-generaattoriyhdistelmien hyötysuhteet ovat alle $40 \%$. Jos moottorin hukkalämpö hyödynnetään, silloin saadaan energiasuhteeksi $2-3,5$.

Kun biomassaa jalostetaan erilaisiksi polttoaineiksi, niiden energiasuhteet huonontuvat. Joissakin tapauksissa energiasuhde voi olla alle yhden, eli tuotantoon tarvitaan enemmän energiaa mitä tuotteessa on. Energia-analyysi paljastaa myös tuotannon ongelmakohdat. Viljan viljelyssä eniten energiaa tarvitsevat lannoitteiden valmistus ja kuivaaminen. Näitä

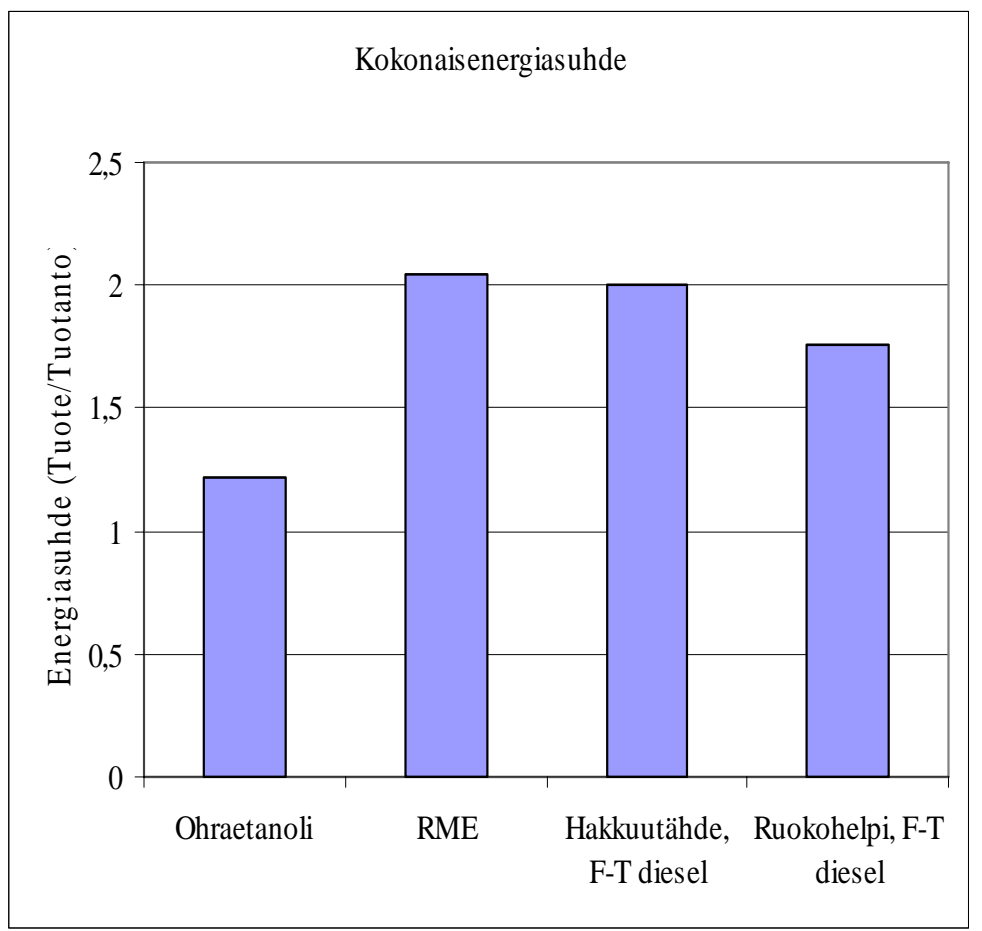

Kuva 3. Bioenergian tuotannon energiataseita (Mäkinen ym 2006) energian kulutuksia pitäisi pystyä vähentämään, koska niiden osuudet ovat suuret. Energia-analyysit eivät ole yksiselitteisiä ja niistä puuttuu yhteinen menettelytapa. Rajaamalla analyysiä eri tavoilla saadaan hyvinkin poikkeavia tuloksia. Etenkin epäsuoran energiakulutuksen arvioinnissa voi olla huomattaviakin eroja (Ahokas ja Mikkola 2007).

\section{Peltobioenergian päästöanalyysi}

Energia-analyysin lisäksi biopolttoaineille tehdään kasvihuonekaasuanalyysi. Siinä tarkastellaan tuotannon päästöjä ja verrataan tilannetta fossiilisten polttoaineiden käyttöön. Päästöt syntyvät biopolttoaineen tuotannossa ja käytössä. Tuotannossa joudutaan käyttämään energiaa, josta syntyy omat päästönsä. Lisäksi tähän tulevat lannoituksesta ja maan elintoiminnoista johtuvat päästöt. Analyysissä käytetään lähes poikkeuksetta IPCC:n kasvihuonekaasupäästöjen arviointimenetelmiä. Ilmaston lämpenemisen vaikutusta tarkastellaan hiilidioksidin, metaanin ja typpioksiduulin kautta. Kun tarkastellaan 100 vuoden jaksoa, metaanin painokerroin hiilidioksidiin verrattuna on 21 ja typpioksiduulin 310. Kertoimet kuvaavat näiden kaasujen vaikutusta ilmaston lämpenemiseen. Metaani ja typpioksiduuli ovat tässä mielessä huomattavasti hiilidioksidia vaarallisempia. Typpioksiduulipäästöjen osalta käytetyt päästöarvot eivät ole kovin tarkkoja, niiden epävarmuudeksi on Suomessa arvioitu - 104 \% - +171 \% (Monni ym. 2007). Ongelmalliseksi tämän päästön tekee sen syntytapa eli sitä syntyy eniten märissä olosuhteissa, jolloin sää ja ojitus vaikuttavat päästömääriin. Myöskin laskentatapa on herättänyt kritiikkiä, koska päästöt kohdistetaan kokonaan tuotannolle ottamatta huomioon luonnon omaa taustapäästöä (Antikainen ym. 2007).

Kuvassa 4 on esitetty Mäkinen ym. (2006) mukaiset kasvihuonekaasupäästöarviot tuotettua energiasisältöä kohti. Sen mukaisesti etanolin (EtOH) ja biodieselin (RME) tuotanto ja käyttö aiheuttavat suuremmat kasvihuonekaasupäästöt kuin fossiilisten polttoaineiden suora käyttö. Pienimmät kasvihuonekaasupäästöt on biomassasta Fischer-

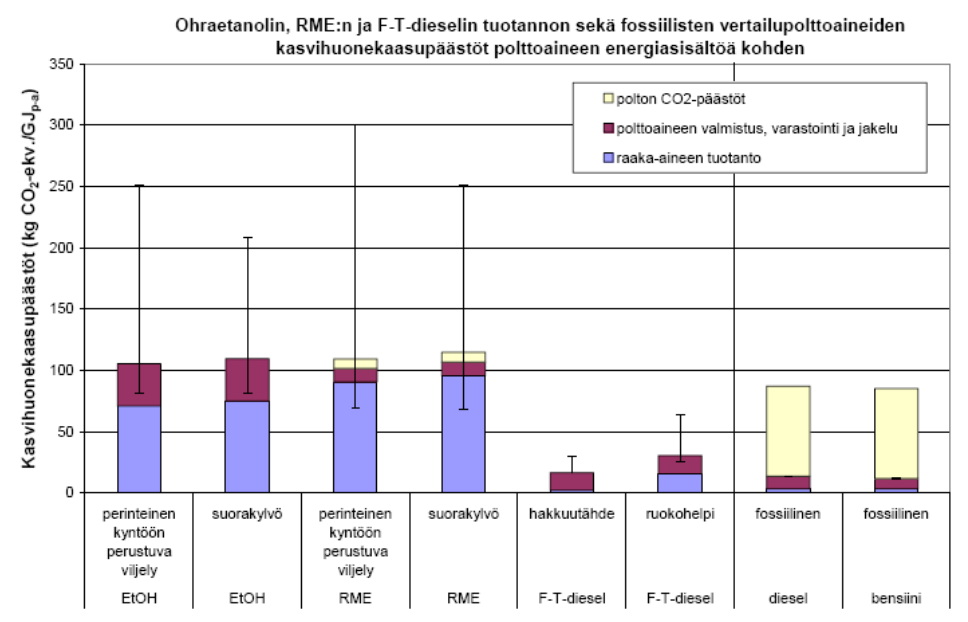

Kuva 4. Biopolttoaineiden kasvihuonekaasupäästöt (Mäkinen ym. 2006) 
Tropsch menetelmällä valmistetuilla biopolttoaineilla.

\section{Peltobioenergian käytön tekniset edellytykset}

Biopolttoaineita verrataan usein vain yhdestä näkökulmasta ja unohdetaan kokonaisuuden tarkastelu. Biopolttoaineiden käytölle on monia teknisiä ongelmia, jotka vaativat ratkaisunsa. Nykyiset polttomoottorit on viritetty kaupallisesti saatavissa oleville ja tasalaatuisille polttoaineille. Samoin niiden päästöt on mitattu näitä polttoainelaatuja käyttäen. Biopolttoneste on monesti laadultaan huonompaa ja laatuvaihtelut ovat suuremmat. Tämä voi aiheuttaa polttoainelaitteiden ja itse moottorin rikkoontumisia sekä kohonneita päästöarvoja. Lisäksi polttoaineiden poikkeavat ominaisuudet voivat aiheuttaa tiivistemateriaalien rikkoontumisia. Moottoreiden biodieselvalmiudet vaihtelevat ja eri valmistajat sallivat erilaisia seossuhteita. Jalostamattoman kasviöljyn käyttö aikaansaa useimmiten moottorin karstoittumisen ja sitä kautta sen kestoikä lyhenee. Meillä kylmäkäyttö aiheuttaa omat ongelmansa. Biodieselissä voi tapahtua polttoaineen kiteytymistä, mikä tukkii polttoainejärjestelmän. Samoin etanolin käytöllä polttoaineen seassa on omat ongelmansa, se voi johtaa etanoli ja bensiinifaasien erottumiseen polttoainesäiliössä. (Schäfer ym. 1986, Mikkonen 2007, Ylivakeri 2007).

Poltossa eri biomassojen polttoaineominaisuudet poikkeavat toisistaan. Esimerkiksi oljen ja myös muiden samanlaisten korsimateriaalien poltossa ongelmana on usein polttoaineen suuri tuhkapitoisuus ja tuhkan alhainen sulamispiste. Lisäksi näiden materiaalien irtotilavuus on alhainen, kosteus voi olla korkea ja niissä on syövyttäviä aineita, jotka voivat aiheuttaa kattilamateriaaleihin korroosiota. Tämä vaikuttaa polttolaitteen rakenteeseen ja myös varastotilan tarpeeseen ja kuljetuskustannuksiin. Polttoaineen kosteus taasen vaatii oikea-aikaista korjuuta tai kuivaamista. (Ahokas ym 1983, Anon. 1998)

Biokaasu vaati myös käyttöönsä ja biomassan hankintaan oman teknologiansa. Biokaasulaitteisto vaatii reaktorin ja kaasuvaraston rakentamisen, ja jos sillä tuotetaan sähköä, tarvitaan moottorigeneraattoriyhdistelmä, joka on yhdistetty sähköverkkoon. Biomassa korjataan normaalisti kesän tai syksyn aikana ja se käytetään pääasiallisesti talven aikana. Käyttökelpoisin varastointimuoto on säilörehu. Kaasutus ei vähennä materiaalin määrää kovinkaan paljon, koska suurin osa siitä on vettä. Siksi täytyy huolehtia myös reaktorista tulevan lietteen eli rejektin käytöstä ja varastoinnista. Nämä kaikki vaiheet vaativat investointeja ja jatkuvaa tarkkailua ja työtä.

Jos biokaasua käytetään moottoripolttoaineena, siitä pitää poistaa hiilidioksidia (sekä mahdollisesti myös muita yhdisteitä) ja liikkuvaa kalustoa varten biokaasu on paineistettava. Paineistuksesta huolimatta kaasun energiatiheys on alhainen ja tankkausvälit ovat lyhyitä.

Uusien energiakasvien viljelyyn ottaminen vaatii myös niille sopivan korjuu- ja käsittelyteknologian. Esimerkiksi maissin viljely biokaasutuotantoon tarvitsee maissille sopivia korjuukoneita, jota meillä ei luontaisesti ole maassamme saatavissa. Samoin ruokohelven korjuussa on huomattu, että korjuutappiot voivat olla 50 - 60\%. Tappioita voidaan pienentää oikealla koneiden valinnalla ja oikea-aikaisella korjuulla (Lötjönen 2007).

\section{Peltobioenergian käytön biologiset edellytykset}

Nykyisin kasvintuotanto tapahtuu pääasiassa ruuan tai rehun tuotantoa varten. Energian tuotannon vaatimukset poikkeavat näistä ja siihen tarvitaan erilaisia kasveja, joita pitää jalostaa energian tuotannon kannalta. Viljelyä pitää myös kehittää edelleen, lannoitus on suurimpia tuotannon energian tarvitsijoita. Tätä riippuvuutta voidaan vähentää paremmalla ravinteiden kierrolla (esim. biokaasu) ja käyttämällä viljelyssä typensitojakasveja, jolloin typpilannoitustarve vähenee, tuotannon energiasuhteet paranevat ja kasvihuonekaasupäästöt vähenevät (Stoddard 2007).

Yhdyskuntajätettä voitaisiin myös käyttää energiakasvien ravinteena. Bioenergiamassalla ei ole samanlaista hygieniavaatimusta, kuin ruuan- ja rehuntuotannossa. Maahan voi jäädä raskasmetallikertymiä, jolloin sitä ei voida enää käyttää ruuan ja rehun tuotantoon. Samoin marginaalisia ja jo pilaantuneita maita voitaisiin käyttää energian tuotantoon.

Biokaasun tuotanto perustuu oikeanlaiseen kaasutettavaan materiaaliin ja mikrobeihin. Mikrobit eivät pysty biokaasuprosessin aikana hajottamaan ligniiniä, minkä vuoksi korsiintunut massa tuottaa vähemmän biokaasua kuin varhaisemmalla kasvuasteella korjattu kasvimassa. Sian lannasta saadaan enemmän kaasua kuin lehmän lannasta, koska lehmän läpi kulkiessaan kasvi on jo kerran käynyt läpi biokaasuprosessin. Lanta tulisi nähdä lähinnä mikrobiston kasvualustana, johon kannattaa lisätä rasvoja ja hiilihydraatteja kaasuntuotannon tehostamiseksi. Itse prosessi tarvitsee sille sopivan lämpötilan ja seoksen, jolloin prosessia on säädettävä, jotta saadaan tehokas kaasun tuotto. 


\section{Peltobioenergian käytön taloudelliset edellytykset}

Bioenergia vaatii aina investointeja ja lisäksi fossiiliset polttoaineet ovat kuitenkin niin halpoja, että biopolttoaineet eivät pysty kilpailemaan hinnaltaan niiden kanssa. Esimerkiksi rypsin osalta raaka-ainekustannukset ovat jo suuremmat kuin saman energiamäärän ostaminen polttoöljynä. Myöskin taloudelliselta kannalta on tärkeää, että koko biomassa pystytään hyödyntämään. Esimerkiksi rypsiöljyn tuotannossa puriste pitäisi saada hyödynnettyä rehuna.

Bioenergian hinta on yleensä fossiilisia polttoaineita kalliimpi, ja jos bioenergiaa halutaan suosia, tämä tietää sen tuotannon tai käytön taloudellista tukemista tavalla tai toisella tai lainsäädännöllistä pakko, kuten liikenteen biopolttoaineiden kohdalla tehdään.

\section{Johtopäätökset}

Tällä hetkellä osa peltoalasta voidaan muuttaa bioenergian tuotantoon ja sillä voidaan korvata osa fossiilisen energian käytöstä. Peltoa voidaan kuitenkin myöhemmin tarvita ruuan ja rehun tuotantoon, joten peltobioenergia ei välttämättä ole lopullinen ratkaisu. Sekä kasvi- että eläintuotannossa syntyy ylitteitä (olki, lanta, viljan, juuresten ja perunan lajittelujätteet, kuorimojäte ja pesuvedet ), jotka voitaisiin joka tapauksessa hyödyntää. Peltobioenergian tuotantoa täytyy kehittää kokonaisvaltaisesti edelleen siten, että otetaan tarkasteluun mukaan kaikki näkökannat ja pyritään saamaan aikaiseksi ekologinen ja kestävä ratkaisu.

Peltobioenergian tuotantoon liittyvät analyysit eivät ole nykyisellään kovin tarkkoja, päästömääriä ei tunneta kovin tarkasti ja lisäksi niihin vaikuttaa voimakkaasti sää ja myös maan kunto. Epävarmuuden on arvioitu olevan jopa 100 prosentin luokkaa. Analyyseissä pitäisi päästä tarkempiin arvioihin, tämä tietäisi menetelmien standardisointia sekä lähtötietojen tarkempaa selvitystä.

\section{Kirjallisuus}

Ahokas J., Ståhlberg P. \& Maaskola I. Olki polttoaineena. Vihti, Valtion maatalouskoneiden tutkimuslaitos, 1983.98 s. VAKOLAn tutkimusselostus nro 30.

Ahokas J. \& Mikkola H. A method to include manufacturing energy in energy balance analysis. NJF Seminar 405, Production and utilization of crops for energy. Vilnius, Lithuania, 25-26.9.2007.

Anon. 1998. Straw for Energy Production Technology - Environment - Economy. The Centre for Biomass Technology. Danish Energy Agency 1998.

Anon. 2007a. World Population Information. http://www.census.gov/ipc/www/idb/worldpopinfo.html. Viitattu 5.11.2007

Anon. 2007b. Arvio biomassan pitkän aikavälin hyödyntämismahdollisuuksista Suomessa. Asiantuntijatyöryhmän raportti. http://www.ktm.fi/files/17251/RintalanBiomassatyoryhma022007.pdf . Viitattu 13.11.2007

Antikainen R., Tenhunen J., Ilomäki M, Mickwitz P., Punttila P.,Puustinen M., Seppälä J. \& Kauppi L. Bioenergian uudet haasteet Suomessa ja niiden ympäristönäkökohdat : nykytilakatsaus. Suomen ympäristökeskus 2007 . Suomen ympäristökeskuksen raportteja ; 2007, 11

Berglund M. \& Börjesson P. Assessment of energy performance in the life-cycle of biogas production. Biomass and Bioenergy 30 (2006).

Cavalchini A.G. Forage Crops. CIGR Handbook of Agricultural Engineering Volume III. American Society of Agricultural Engineers, 1999.

Ortiz-Canavate J. and Hernanz J.L. Energy Analysis and Saving. CIGR Handbook of Agricultural Engineering Volume V. American Society of Agricultural Engineers, 1999.

Kitani O. Natural Energy and Biomass. CIGR Handbook of Agricultural Engineering Volume V. American Society of Agricultural Engineers, 1999.

Lötjönen T. Harvest losses in reed canary grass. NJF Seminar 405, Production and utilization of crops for energy. Vilnius, Lithuania, 25-26.9.2007.

Mikkonen S. Tulevaisuuden nestemäiset polttoaineet. Agtek370 - Bioenergiaketjut kurssimateriaali.

Monni S., Perälä P. \& Regina K. Uncertainty in Agricultural $\mathrm{CH}_{4}$ and $\mathrm{N}_{2} \mathrm{O}$ Emissons from Finland - Possibilities to Increase Accuracy in Emission Estimates. Mitigation and Adaptation Strategies for Global Change (2007) 12: 545-571

Mäkinen T., Soimakallio S., Paappanen T., Pahkala K. \& Mikkola H. Liikenteen biopolttoaineiden ja peltoenergian kasvihuonekaasutaseet ja uudet liiketoimintakonseptit. VTT Tiedotteita 2357, Espoo 2006.

Schäfer W., Luomi V., Palva T., Parmala S-P. \& Ahokas J. Kasviöljyt dieselmoottorin polttoaineena. Vihti, Valtion maatalousteknologian tutkimuslaitos, 1986. 40 s. VAKOLAn tutkimusselostus nro 42.

Stoddard F. The role of legumes in bioenergy production. NJF Seminar 405, Production and utilization of crops for energy. Vilnius, Lithuania, 25-26.9.2007.

Tietohaarukka - Tilastotietoa elintarvikealasta 2007. FinFood - Suomen ruokatieto ry.

Tuomisto H. Peltobiokaasu liikenteen biopolttoainevaihtoehtona energia-, kasvihuonekaasu- ja ravinnetaseiden kannalta. Pro gradu -tutkielma, Helsingin yliopisto, Soveltavan biologian laitos, Agroekologia, Syyskuu 2006 
SUOMEN MAATALOUSTIETEELLISEN SEURAN TIEDOTE NRO 23

Ylivakeri M. Vaihtoehtoiset polttoaineet. Tekninen soveltuvuus dieselmoottoreihin. Agroteknologiaverkoston neuvottelupäivät 23.10.2007 Jyväskylä. 